\title{
Catenin Delta-2
}

National Cancer Institute

\section{Source}

National Cancer Institute. Catenin Delta-2. NCI Thesaurus. Code C82943.

Catenin delta-2 (1225 aa, $133 \mathrm{kDa})$ is encoded by the human CT NND2 gene. This protein is involved in transcriptional activation and signal transduction. 